
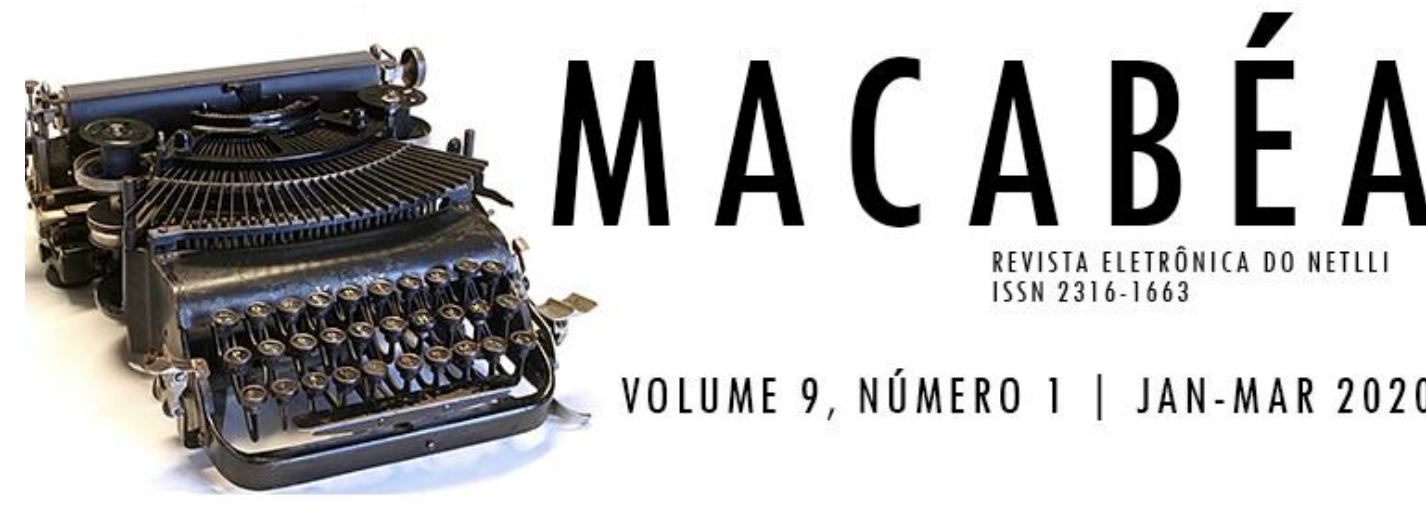

REVISTA ELETRÔNICA DO NETLLI ISSN 2316-1663

VOLUME 9, NÚMERO I | JAN-MAR 2020

\title{
CHAINS AND WHIPS EXCITE ME: A DISCUSSION OF BDSM PRACTICES IN BEAUTY'S KINGDOM
}

\section{CHAINS AND WHIPS EXCITE ME: UMA DISCUSSÃO DE PRÁTICAS BDSM EM “O REINO DE BELA”}

\section{Paola Nichele UNIVERSIDADE FEDERAL DE SANTA CATARINA, Brasil} RECEBIDO EM 17/10/2019 APROVADO EM 08/12/2019

\section{Abstract}

This study analyses the novel Beauty's Kingdom (2015), written by Anne Rice - a novel that presents BDSM (Bondage/Discipline, Dominance/Submission, Sadism/Masochism) relations through voluntary sexual submission. The volume chosen was published in 2015 , four years after the publication of Fifty Shades of Grey (2011), a novel responsible for the popularization of erotic literature for a female readership. The main objective of this research is to look for BDSM representations that go beyond the existent debate on pro or against the practice and present possibilities to rethink such practices, as proposed by the scholar Margot Weiss. 


\section{Resumo}

Este trabalho analisa o romance O Reino da Bela (2015), escrito por Anne Rice - romance que apresenta relações de BDSM (Bondage/Disciplina, Dominação/Submissão, Sadismo/Masoquismo) através da submissão sexual voluntária. O volume analisado foi publicado em 2015, quatro anos após a publicação de Cinquenta Tons de Cinza (2011), que trouxe consigo a popularização da literatura erótica voltada ao público feminino. O objetivo principal do trabalho é procurar possíveis representações de BDSM que vão além dos debates existentes sobre o assunto sobre favorável ou contrário e, assim, apresentam a possibilidade de repensar tais práticas; para a definição de práticas que se propõem a repensar relações de BDSM trabalho com a proposta da teórica Margot Weiss.

\section{Entradas para indexação}

KEYWORDS: Erotic Literature; BDSM; Sexuality; Feminism; Beauty's Kingdom.

PALAVRAS-CHAVE: Literatura Erótica; BDSM; Sexualidade; Feminismo; 0 Reino de Bela.

\section{Texto integral}

\section{INTRODUCTION}

Erotic literature has been published for a long time, and its significance has changed throughout different moments in society. According to Sarane Alexandrian, for the ancient Greeks and Romans, erotic stories were considered harmless, a mere entertainment. But then, in western society, stoic philosophers started a call for "decency," and anything related to sex was considered impure and forbidden (Alexandrian 31). However, erotic literature did not cease to exist; it just survived on the margins.

While the genre remained on the margins, erotic literature written by women suffered from an extensive repression; not because it was considered impure or subversive, but due to the repression of women's sexuality itself. It was not acceptable for women to write about the erotic because they were supposed to be "romantic," as stated by Alexandrian, in The History of Erotic Literature (1993), in which he says that women should only write within the sentimental genre, in which they are insuperable (328).

Regardless of Alexandrian's belief about the low acceptability of women writing erotic novels, the number of women using this genre increased; and women started writing erotic novels for a female audience. Nowadays erotic novels written by women have become popular; the scholar Amber Jamila Musser mentions the novel Fifty Shades of Grey as responsible for popularizing erotic 
novels among women, and Musser also states that this was not the first novel to address issues as BDSM within erotic literature written by women, since Story of 0 , published in 1954, already dealt with such theme (122).

\section{BDSM}

The scholar Lewis Call, author of BDSM in America Science Fiction and Fantasy (2013), presents a discussion about BDSM within literature and makes a brief introduction to BDSM practices. The term BDSM, as Call says, belongs to the present generation, since the previous generations would have the acronyms DS (dominance/ submission) and SM (sadism/ masochism) separating the practices. BDSM, on the other hand, "reflects a desire to embrace the greatest possible plurality of practices" (2). Call explains that BDSM practitioners tend to be part of communities where they can express and explore their desires separated from the "vanilla" - non-practitioner of BDSM - world (2). Within BDSM practices there is a variety of nominations to categorize the role of the participants, as Call explains:

A man who takes on a dominant role can be called a Dom; a dominant woman is often referred to as Domme. A submissive of either gender can be designated as sub. The most dramatic form of the Dom(me)/sub dynamic is erotic play-slavery, a type of power exchange which mimics the form of chattel slavery (...). The dominant partner in a play-slavery relationship is the Master (male) or Mistress (female); the submissive partner is called a slave. The terms "top" and "bottom" usually refer to the more physical kinds of play. A top is someone who gives physical sensation (e.g. pain); while a bottom receives such sensation (Call 7).

Being a bottom is not necessarily related to being submissive (7); such variety of nominations and roles also allow the practitioners to switch roles, and because of that, another category was created: the "switchers" (Call 8).

There is an extensive discussion, mostly by feminist scholars, on the role of BDSM relations; if those relations adhere to patriarchal values and undermine women, or if it can be perceived as a means of sexual liberation. Debates about sexuality, inserted within a feminist context, are usually polarized between Radical and Libertarian feminists. For the discussion regarding BDSM relations, Radical feminists are against BDSM and understand it as a reproduction of male dominance. On the other hand, Libertarian feminists claim that every sexual practice is an act of sexual freedom and empowerment, as long as it is consensual. According to author Patrick Hopkins, in the late 1970s it was pretty shocking for feminist activists of the time when women declared that they were feminists and sadomasochists (116).

To better explain the specific sex war this research draws on I will rely on Ann Ferguson's article entitled "Sex War: The Debate between Radical and Libertarian Feminists" (1984). Ferguson explains that by the 1980s, when discussions about sexuality became an issue in Academia, feminists identified themselves in two groups: Radical and Libertarian. Radical feminists would 
criticize sadomasochism, pornography and prostitution arguing that they perpetuate male dominance; on the other hand, the libertarian feminists would support any kind of consensual sexual practice that brings pleasure to the ones involved (107).

Among distinct perspectives regarding BDSM practices within feminism there are authors who believe that a binary discussion, considering pros or cons, would not be enough to fully discuss the implication of such practice. Ferguson, in the aforementioned article, demonstrates concern with such debate, arguing that women should have the possibility to choose whether they want to engage in such practices without feeling guilty (112). The Scholar Lynn S. Chancer also advocates in favor of a broader discussion regarding BDSM arguing that is fundamental to rethink BDSM practices; Chancer fears that if the feminist movement represses women who are BDSM practitioners, it may risk "reproducing another version of sexual repression" (83). Chancer suggests that the focus should not be on individual choices, but in the whole context in which such practice is inserted and what it represents. She compares it to discussions related to pornography: it should not be centered on whether a woman enjoys watching it or not, but on the porn industry itself. Therefore, discussions about BDSM should not focus on whether women enjoy it or not, but on the implications of such practices and what they represent for its participants. Building from Chancer's arguments about the need to rethink BDSM practices, one of the objectives of this research is to rethink BDSM practices considering how practices may vary depending on its participants, and which elements participants can bring to practices that will significantly alter their meaning.

Margot Weiss, author of BDSM and the Circuits of Sexuality (2011), also adds to the discussion about rethinking BDSM practices, proposing to analyze BDSM scenes considering elements such as "social location, audience reception, and discursive and ideological production" (188), for the BDSM scene to be effective and political, it connects the real (social) with the scene (performance), without drawing a line between what is fantasy and what is real. Weiss argues that some BDSM practitioners "justify social inequality (based on race, class, and gender) through purportedly neutral subjectivity" (189) which make those practitioners who are part of the dominant group - such as man, white, and middle-class - exempt from oppressive social norms; and therefore reinforcing their own privileges. As an example of such privileges, the author Robin Bauer discusses the uses of terms such as "master" and "slave," pointing out that among BDSM practitioners, mainly white people, there is no politicization of such terms; issues such as gender and class are constantly addressed in BDSM scenes, while race is put aside and depoliticized, which Bauer claims to be "a white privilege not to concern oneself with one's racial status and history when playing as slave" (246).

It is important, and necessary, to discuss and problematize BDSM practices. However, is also important not to condemn it. Gayle Rubin, as a practitioner of sadomasochism, reports how sadomasochism was demonized when she "came out" and assumed she was a feminist and a sadomasochist. Additionally, Rubin mentions how uncomfortable she felt when reading the feminist press, because she 
wondered "what vile picture of my sexuality will appear this month" (211). Although there are many points within BDSM practices that need to be deeply discussed, and are indeed problematic, the practitioners can question and maybe subvert them.

Acknowledging the arguments existent about the debate on BDSM and feminism, I will follow Chancer's discussion about the need to rethink BDSM practices, focusing on how different people within BDSM may have distinct ways to address the practice. I will move beyond the existent debate about BDSM and arguments pro or con, and consider a third perspective to analyze BDSM practices by rethinking it. This perspective is built from the theory proposed by Lynn S. Chancer, in her article "From Pornography to Sadomasochism: Reconciling Feminist Differences" and Margot Weiss' perspective presented in the book Techniques of Pleasure: BDSM and the Circuits of Sexuality.

\section{BEAUTY'S KINGDOM}

In my search for contemporary erotic novels that portrayed BDSM relations I found the novel Beauty's Kingdom, by Anne Rice. The novel is the fourth volume of what should be the Sleeping Beauty Trilogy. Throughout the three volumes, entitled The Claiming of Sleeping Beauty (1983), Beauty's Punishment (1984), and Beauty's Release (1985), Rice, writing under the pen name A. N. Roquelaure, introduces a new version of the fairy tale Sleeping Beauty, in a medieval kingdom where people are trained to be sexual slaves or masters - the slaves being usually forced to be in the castle, having no right to complain or disobey.

What is now called the Sleeping Beauty Quartet should have ended in the third volume of the series; Anne Rice published the fourth volume thirty years after the last volume of her initial trilogy, a time in which erotic novels are being popularized. The fourth volume of the Sleeping Beauty Quartet called my attention in relation to a change in the narrative from the three initial books: in the fourth book, entitled Beauty's Kingdom, the main character, Beauty, would run the Kingdom and decree that every sexual slave in the castle should be voluntary and have the free will to choose whether they wanted to remain in the kingdom. The fourth volume of the quartet is more appealing to me because of a change in the narrative, which is the possibility of choice and consent - an important issue when debating BDSM. The novel does not necessarily addresses the rules and ethics of BDSM explicitly, but the BDSM representations in Sleeping Beauty Quartet are perceived through the sexual relations among the characters, such as spanking, bondage, humiliation, psychological and physical domination in general; such interactions are read as BDSM scenes, making possible the analysis of the novel as BDSM representations.

The beginning of the Sleeping Beauty Trilogy already sets the mood of the whole quartet: the Sleeping Beauty is not awakened by Prince charming with a romantic kiss; but raped by a Prince who takes her to his kingdom and turns her into a sex slave. Beauty is not the only slave in the kingdom; as it turns out, her

Macabéa - Revista Eletrônica do Netlli | V.9., N.1., JAN.-MAR. 2020, p. 178-191. 
parents had been slaves in the same place, and since the Prince woke her up and saved her kingdom - they were all asleep until Beauty was awakened - it was now her duty to serve Queen's Eleanor - the new ruler of the kingdom her parents had served. Not everyone could be a sex slave in the kingdom of Bellavalten, only the "young royalty." The BDSM scenario and the presence of sex slaves are not a reality in the whole fictional world of the Sleeping Beauty Trilogy; there are other villages and kingdoms that do not follow the example of the kingdom of Bellavalten.

\section{BE THE CHANGE}

This section analyzes Beauty's Kingdom passages and characters that provide the possibility for a reading of BDSM representation that rethink the practice.

The first character I am going to discuss is Dmitri, a former slave who has returned to Bellavalten, this time to act as a master. While Dmitri is walking around Bellavalten, he meets a slave named Barbara, who is being punished in the public whipping at the village. She was being punished because she did not behave as a proper slave, just as he was not used to being a well-behaved slave, so he gives her a coin - one of the traditions of the kingdom is to give coins to the slaves after their punishments - saying "Bad girl. Take it from a bad boy. I know" (149), which demonstrates Dmitri's empathy towards this slave. Dmitri then decides to ask for Barbara as a slave, because he identifies with her; Dmitri understands the burdens of being considered a bad slave, so his request to have Barbara as his own slave represents not only his identification with her, but the way in which he treats her demonstrates his guilt towards the kingdom's tradition, since he does not act as an average master; which would be to punish the slaves and feel no remorse about it. Barbara is sent to Dmitri's place and he does what is expected from a master: spanks her. However, as he finishes the spanking session he covers her face with kisses and then realizes that he is crying while thinking to himself "I wanted you, I am you" (171). Dmitri's thought of "I am you" relates to other moments of the narrative, as a passage in which he is watching slaves being punished and thinks "How many times had I been ordered to do that, and to stand silent for the inspection of the most intimate sort?" (117); he also remembers the punishments he suffered, "it was all tangled. I felt myself, naked, sore, crying, being rushed to the pillory" (137), and when he meets a young slave and kisses the boy's face, comparing himself to the boy "he was my height. Utterly passive. When I was new, I'd trembled or shaken every time I was touched or kissed" (218). Dmitri is the only character in the novel who feels empathy towards the slaves; not only because he used to be a slave himself - after all, characters such as Beauty and Laurent, her husband and King, also have been slaves and show no empathy - but because he actually feels annoyed by the punishments, and sorry for the slaves. Dmitri's discomfort regarding the kingdom's rule that if a slave is not considered suitable for the kingdom she/he has to leave in exile, is exemplified when he thinks "if this boy does not please, he will not only be whipped for the next six months, harder and longer and more angrily than other slaves who do please, but sent

Macabéa - Revista Eletrônica do Netlli | V.9., N.1., JAN.-MAR. 2020, p. 178-191. 
away when the period of testing is over" (218) - Dmitri's thoughts about the kingdom may not explicitly show his discomfort or annoyance, but the fact that he is the only character who critically thinks about the punishments indicates that he does not naturalize it.

Dmitri does not feel comfortable with the punishments and the role he has to perform, but he is not powerful enough to change anything; therefore, he just reproduces what he was taught to do; as scholar Jean Baker Miller argues, dominant groups influence behaviors and beliefs. Dmitri is part of a dominant group, since he is noble and a master; he repeats values from the dominant culture - he reproduces the belief that the slaves have to submit to him, and that his function is to punish and discipline them; however, as he has sex with Barbara, he is concerned with her pleasure, as the following passage shows

I pressed my tongue into her, tasting her delicious smoking and fragrant juices. I lapped at her juices. Her hips rode up and down helplessly under me. With my mouth over her clitoris, over her gasping sex, I knew she had no control, and I stabbed at her clitoris with my tongue until she came without stinting. On and on she came, abandoned to the pleasure (Rice 168).

The passage above indicates that Dmitri is in control of the sexual act, as in "I knew she had no control", but even while in control, he is concerned with giving pleasure to Barbara.

Still on the topic of characters who have the power to change the kingdom's tradition, the Queen, Beauty, also demonstrates some concern with the slaves. When Beauty first meets the slave Blanche, who would rather die than disappoint the Queen, Blanche cannot control herself, so she ends up having an orgasm in front of the Queen. Instead of punishing Blanche, as other masters would have done, Beauty calms her down by saying "You have pleased me very much, precious Blanche. I shall always love you, love you especially for this night" (97). However, Beauty's constant demonstration of love with her slaves is not related to empathy or concern with their wellbeing, but to the narrative's attempt to show that Beauty is not suitable to act as a mistress; she is not dominant, but submissive.

The punishments suffer some alterations after Beauty becomes Queen. In the main square of the village there are constant whippings, and specific lashers who are responsible for it. In one of the whipping sessions, Dmitri sees a lasher who "crooned to the slave bent over his apron now, tousling his hair, and stroking his back, and patting his upturned backside gently" (142), this kind of treatment is called "aftercare" in BDSM practices. The author Catherine Scott mentions the importance of the aftercare after an intense BDSM session (14); it shows concern with the submissive and her/his wellbeing; such act was not present in Eleanor's kingdom - the slaves were supposed to be beaten and suffer, while masters and lashers punished them, demonstrating no emotional involvement with the slaves.

Another character who does not naturalize every kingdom's tradition and makes an effort to problematize them is Tristan, a noble and master in the kingdom, who questions one of the sexist arguments made by another character, who says "I suspect that severity must come from a man," to which Tristan asks back "But shouldn't he be taught to obey both men and women?" (280). 
In order to rethink BDSM practices, that in the novel would be the kingdom's tradition regarding the erotic slaves, it is important to consider not only the practice itself, but the political choices and beliefs of the practitioners. Although Tristan does not feel empathy towards the slaves as Dmitri does, his questioning about a sexist statement could represent a possibility to rethink the kingdom's traditions, especially those that reinforce the notion that women are submissive and passive, while men are dominant and strong. I say that Tristan's questioning could represent a possibility to rethink the kingdom's practice because it would only happen if his questioning was taken further and, in fact, discussed or considered in other moments of the narrative; however, his questioning is discarded by Lady Eva's answer: "once he's broken and trained [...] he will submit to either with good manners" (280), and the subject is rejected as soon as the passage is over.

The novel presents passages in which gender roles are challenged. Once Queen and King, Beauty and Laurent would have relations with the slaves of the kingdom who would be there to serve and please them. The novel is set in a medieval time, and in medieval times the King could have relation with other women, as Beauty reminds Laurent (33); but Bellavalten is different from other kingdoms. As they discuss whether to accept the invitation, Beauty reminds Laurent that "that is the way of Bellavalten, that a woman may have what a man has, and men and women must serve men and women," [italics added] (Rice 33) in order to make it clear that, if they go to Bellavalten, Beauty would have the right to have relations with other people, what makes Laurent hesitate for a moment. Beauty states that "I will be the only Queen of your heart, and you the only king of mine, but the pleasures of the kingdom will be enjoyed by both of us" (33). In this passage Beauty emphasizes her wish - and her power - to be involved with other people, what confronts traditional monogamist relationship.

The question of gender roles is brought back in the narrative when Beauty finds out about a group of women who "passed as men, as grooms, dressing as men, living as men" (251), so they were caught by the former Queen, Eleanor, and had to leave the kingdom in exile. This group wants to return to the kingdom, and it is Beauty's decision to allow them or not, to which Beauty quickly answers "Why should they not live as men if they choose? [...] What harm have they done? So let them do as they like" (251). Although the characters do not have the possibility to switch their roles as dominant and submissive, the narrative provides representations of gender fluidity; be it in the relationships of characters among themselves that is not necessarily aligned with heterosexual representations, or in the portrayal of those women who wish to live as men. When Beauty allows those women to return to Bellavalten, she is representing a change in at least one of the kingdom's rule: while Queen Eleanor exiled those people for not acting according to the kingdom's expectations towards gender representativeness, Beauty is open to this group's decision to live as men.

Gender representations are once more presented in the narrative when Beauty gets familiarized with the kingdom Khaharanka, in which there are only women inhabitants, and where the queen "is a goddess [...]. She and her Court of women are held to be divine beings of unquestioned authority" (329). Differently

Macabéa - Revista Eletrônica do Netlli | V.9., N.1., JAN.-MAR. 2020, p. 178-191. 
from the continuous repetition of women as inherently submissive and men as inherently dominant, in the kingdom of Khaharanka women are strong and in positions of power. Moreover, men can be part of Khaharanka as well, but they have to drink a potion that gives them female features - at this point, the novel addresses gender subversion, presenting characters that have both male and female characteristics; as Beauty notices it, she thinks to herself: "I was staring at a gorgeous androgynous god" (332).

The possibility to rethink the practices of the erotic slave's in Bellavalten is not strong enough when focusing on the characters that disrupt some of the kingdom's traditions. Dmitri, the character with the strongest potential to represent a change, does not have enough power to influence his pairs; Tristan barely has a chance to question; and Beauty, the Queen, sees the slaves as "Bellavalten's treasure," those who provide money and sustain the economy of the kingdom by being used as touristic attraction, although the premise of her reign is to bring changes to Bellavalten - as the voluntary erotic slavery - she holds the main kingdom's traditions, keeping slaves as products and having little concern with their desires.

\section{POLITICAL EFFECTS}

Margot Weiss suggests that a political reading of BDSM must consider the social position of the practitioners and the effects that a scene has on its participants - beyond the practitioners' intentions. As Weiss argued, the practice is affect by its practitioners and their social context, and it can be "transformational when it connects the scene to the social (...) and the audience must risk identification with the bodies and social imaginaries at play" (277). Since my analysis is focused on a literary representation of BDSM scenes, the identification is not on bodies, but on characters and narratives. Weiss also presents an approach considering rethinking BDSM practices, claiming that, in order to analyze a BDSM scene, it is necessary to consider elements such as "social location, audience reception, and discursive ideological production" (188). By analyzing BDSM scenes through those elements, Weiss argues that

making sex public can disrupt fantasies of autonomous individualism, personal pathology, individuated responsibility, the privateness of desire, or sex removed from the social. Sometimes, too, circuits can reproduce, reinforce, even establish forms of disavowal and unknowing that enable social privilege and help to justify it. There is no single reading of the SM scene, because scenes depend on the active production of the materiality of social differentiation by players, audiences, and readers. (230)

Some scholars define BDSM as a marginalized practice or a subculture, what does not mean that BDSM is inherently transgressive or politicized. Additionally, I corroborate Weiss' perspective about the influence of BDSM scenes, which is to resist the question about how BDSM scenes subvert social power, but to focus on what are the political contexts and effects of such scenes (229). Sexuality needs to 
be discussed and problematized in relation to social contexts - as gender, race, and class - and not only as an escape (Weiss 231), after all, BDSM scenes reproduce social relations, be it in slavery, rape scenes, interrogatory scenes, and so on. This relation with a larger social context cannot be seen as mere sexual fantasy, if the participants choose to engage in such scenes, they need to be aware of what the practice may reproduce or reinforce - it can corroborate the dominant culture's values, or question it via what Weiss calls "hot-button issues" (189); which is the way in which people who watch the BDSM scene - and for my research those are the readers - engage and identify with the participants of the scene, what effect it will cause on the viewers and readers. BDSM scenes may work as parody or hyperbole, which "can displace norms, exposing the non-naturalness, noninevitableness, or indeterminacy of social power" (Weiss 191). In this section, I will focus specifically on the theme of slavery, and how the usage of terms related to slavery are presented in the novel, if they are problematized, politicized, or if they work as parody or hyperbole, as suggested by Weiss.

\section{SLAVERY}

The narrative of Beauty's Kingdom presents a variety of terms and settings related to slavery. The people responsible for whipping the slaves are called Captains and whipping masters; the usage of whipping appears repeatedly throughout the narrative as one of the main means to punish the slaves, as distinct passages exemplify.

Lady Eva threatens Laurent while he is being dominated, saying "I'll whip you and your ankles and the soles of your feet" (48), so whipping is used as punishment for the submissive, as it can be noticed in Beauty's line: "It was where bad little boys and girls were spanked by a seated whipping master while the villagers gathered to gossip and drink" (92). In this passage, whipping is used as punishment, and also as a source of entertainment for the villagers. Dmitri remembers of the time he used to be part of such entertainment, describing the Public Turntable:

being brought up the ladder to it, and told to kneel over with my chin on the thick square wood post. The crowd had been hooting and cheering. I'd panicked, as always, and within seconds my hands had been placed in the small of my back, my wrists bound tight. The leather straps had gone over my calves binding me to the floor of the turntable, and the whipping master was laughing as he lifted the big wooden paddle in front of my face so I would see it. (Rice 110)

In Dmitri's passage about the Public Turntable it is possible to notice that it was not enjoyable to him, only to those watching him and to the Captain who punishes him, who says "you're giving the crowd a great show. You just keep struggling with all your might against those straps. But keep your chin on this post, or I'll let the crowd name the number of the blows" (112). Dmitri's description of his punishment causes discomfort, since he mentions how he would panic and the whipping master would only laugh; therefore, the reader can feel empathy for

Macabéa - Revista Eletrônica do Netlli | V.9., N.1., JAN.-MAR. 2020, p. 178-191. 
Dmitri, and disgust for his punishers and the people watching the scene and enjoying it. However, as previously mentioned, Dmitri is the only character who questions and reflects about his time as slave, the only one who describes punishments as negative. Other whipping sessions are described romantically, as the following: "[t]he little girl obeyed the whipping master submissively and almost gracefully, at once clasping her hands in the small of her beautifully arched back" (133), and later on "[s]he couldn't keep her calves still, or her feet; she was dancing, as they call it. She couldn't help it. Dancing" (133); the usage of terms such as "gracefully" and "beautifully" sets a mild tone to this whipping section, and when the narrator says that the girl was "dancing," what was supposed to be a punishment is ironically turned into something graceful, and even enjoyable. When one slave is being prepared for her punishment, the whip masters notices that she is "wet" and she reacts by thinking to herself that she could not control it, since the idea of being punished was enough to let het wet.

In another passage, the slave Becca is put in a pillory to spend the night once again, a straight reference to slavery - and when her master checks on her, she welcomes him, as he describes "licked my hand over and over with her pink tongue to show her complete adoration. (...) She'd be dripping with sweet juices when I'd finished with her" (278-279). Besides the aforementioned romanticized description of the whipping session through the perspective of a watcher, the later passage portrays the submissive as thrilled to be whipped.

By representing whipping sessions - especially those in pillories, by master whippings and Captains - the narrative not only naturalizes, but romanticizes slavery and the violence slaves went through; Dmitri's description of the whipping session is the only one in the novel that presents a negative perspective towards whipping.

Terms such as "slave" and "master/mistress" are continuously repeated in the narrative and such terms are not considered as a racial issue - actually, they are not considered an issue at all. The novel does not mention any black character, which corresponds to Robin Bauer and Margot Weiss argument that, white BDSM practitioners have the privilege to use terms related to slavery without problematizing or politicizing them. As Weiss discussions mentioned in the previous section, BDSM scenes can approach polemic topics, even taboos, as slavery or rape, what matters is how such themes are approached. When terms related to slavery are repeated throughout the whole novel without any concern about its usage, what Rice does is to reinforce the white privilege of approaching a theme that is a racial issue, and dealing with it through a "neutral" perspective, as if slavery was not an issue at all. By seeking to rethink BDSM practices, Weiss points out the importance of the political effect that BDSM scenes provoke; in Beauty's Kingdom the narrative presents elements of slavery and, by not discussing it and not politicizing it, the narrative misses the opportunity to have a political effect and remains indifferent to it. 


\section{FINAL REMARKS}

The purpose of this work was to investigate BDSM practices representation in literature - specifically in the novel Beauty's Kingdom - in order to look for representations that go beyond the binary discussion of BDSM as either good or bad, especially in relation to feminism studies. I consider such topic relevant due to the popularization of novels such as Fifty Shades of Grey; erotic literature for a female audience, reproducing gender stereotypes and making use of practices considered to be subversive, such as BDSM, to give a false idea that the narrative is subversive as well, while the main plot is about a naïve/submissive woman being fascinated with a strong/dominant man. With Anne Rice's publication of Beauty's Kingdom and the promising statement that the fourth volume would be different from the previous ones, due to the erotic slavery being voluntary and Beauty - who suffered through the initial narrative as a slave - would become queen, I saw an encouraging narrative that would finally present BDSM practices with the potential it has to subvert gender, class, and race hierarchies. However, such potential was not as present as I had imagined.

Weiss states that BDSM has become a product, and Rice's narrative reproduces this notion. While what Weiss sees as product are BDSM props and clothes, Rice sells the practitioners themselves. Bellavalten's economy is based on erotic slavery as tourist attraction, to which people from other villages are curious about and pay to witness it. Such factor has a considerable influence on the masters and mistresses' relation towards the slaves. Dmitri indeed demonstrates concern because he is also worried about his slave's pleasure, but the preoccupation demonstrated by the Queen, and even the creation of contracts that stated that no marks would be left in the slaves, or that they would be well fed and taken care of, is not a concern with the slaves' wellbeing as people, but as products; the kingdom needs them alive and strong in order to increase Bellavalten's economy.

The notion of slaves as products is reinforced by the fact that slaves cannot have any lands or titles; even if a slave was previously a lord - such as Lord Stefan - they would have to abdicate everything they had, and depend on the kingdom to have habitation and food. The slave's subjection to their masters and mistresses is related to the class hierarchy present in the novel. Master and mistresses are superior not only because they can punish slaves, but they are also economically superior, since they are the ones who can provide for the slaves.

Inserted in this "post Fifty Shades era" the novel Beauty's Kingdom is an attempt to offer to women who enjoy erotic literature a plot in which sex and sexuality are subversive - what can be noticed through the characters who sexually engage with others regardless of their gender. However, as the analysis showed, the plot is not subversive, and many times it relies on gender stereotypes - such as the notion that women are inherently submissive while men are inherently dominant - and class hierarchies, since those who are in power are sexually dominants and also economically superior, which gives them the possibility to control their sexual slaves. For further research on this topic I

Macabéa - Revista Eletrônica do Netlli | V.9., N.1., JAN.-MAR. 2020, p. 178-191. 
suggest a broader analysis of the erotic literature market, focusing on novels written by women, mostly due to the importance of we, as women, be able to read erotic novel that are not undermining or falsely feminist.

\section{Referências}

ALEXANDRIAN, Sarane. História da Literatura Erótica. Rio de Janeiro: Editora Rocco, 1993.

BAUER, Robin. Transgressive and Transformative Gendered Sexual Practices and White Privileges: The Case of the Dyke/trans BDSM Communities. WSQ: Women's Studies Quarterly, Feminist Press, v. 36, n.3, p. 233-253, fall/winter 2008.

CALL, Lewis. BDSM in American Science Fiction and Fantasy. Nova York: Palgrave Macmillan, 2013.

CHANCER, Lynn S. From Pornography to Sadomasochism: Reconciling Feminist Differences. The Annals of the American Academy of Political and Social Science, Sage Publications, v. 571, n. 1, p. 77-88, September 2000.

FERGUSON, Ann. Sex war: The debate between radical and libertarian feminists. Signs: journal of women in culture and society, The University of Chicago Press, v. 10, n.1, p. 106-112, Autumn 1984.

HOPKINS, Patrick D. Rethinking Sadomasochism: Feminism, Interpretation, and Simulation. Hypatia, Wiley, v.9, n.1, p. 116-141, Winter 1994.

MILLER, Jean Baker. The effects of inequality on psychology. In: RIEKER, Patricia Perri et al. The Gender Gap in Psychotherapy. Nova York: Plenum, 1984. p. 45-51.

MUSSER, Amber Jamilla. BDSM and the Boundaries of Criticism: Feminism and Neoliberalismin Fifty Shades of Grey and The Story of O. Feminist Theory, Sage, v.16, n..2, p. 121-136, 2015.

RICE, Anne. Beauty's Kingdom. Nova York: E. P. Dutton, 2015.

RUBIN, Gayle. The leather menace: Comments on politics and S/M. In: RUBIN, Gayle. Deviations: a Gayle Rubin reader. Durham: Duke University Press Book, 2011.

SCOTT, Catherine. Thinking Kink: The Collision of BDSM, Feminism and Popular Culture. Jefferson: McFarland \& Company, 2015.

WEISS, Margot. Techniques of Pleasure: BDSM and the Circuits of Sexuality. Durham: Duke University Press, 2011.

Para citar este artigo

Macabéa - Revista Eletrônica do Netlli | V.9., N.1., JAN.-MAR. 2020, p. 178-191. 
NICHELE, P. Chains and whips excite me: a discussion of bdsm practices in beauty's kingdom. Macabéa - Revista Eletrônica do Netlli, Crato, v. 9., n. 1., 2020, p. 178191.

\section{O Autor}

Paola Nichele é Doutoranda do Programa de Pós-graduação em estudos linguísticos e literários da UFSC. 